\title{
Effectiveness of Riparian Vegetated Filter Strips in Removing Agricultural Nonpoint Source Pollutants in Agricultural Runoff from the Liao River Area, China
}

\author{
Jiaxi Tang ${ }^{1,2}$, Yongle Zhu' ${ }^{2}$, Zhongping Wei ${ }^{3}$, Liangshan Feng ${ }^{1}$, Ning Yang ${ }^{1}$, \\ Zhanxiang Sun ${ }^{1 *}$, Qing Luo $^{4 * *}$ \\ ${ }^{1}$ Liaoning Academy of Agricultural Sciences, Shenyang 110161, China \\ ${ }^{2}$ College of Environmental Science and Engineering, Liaoning Technical University, Fuxin 123000, China \\ ${ }^{3}$ Liaoning Academy of Forestry Science, Shenyang 110032, China \\ ${ }^{4}$ Key Laboratory of Regional Environment and Eco-Remediation of Ministry of Education, \\ College of Environment, Shenyang University, Shenyang 110044, China
}

Received: 24 December 2020

Accepted: 26 February 2021

\begin{abstract}
Riparian vegetated filter strips (RVFS) can effectively intercept agricultural non-point source pollution (ANSP) into a water body and reduce the risk of water body pollution. The present study evaluates the long-term effectiveness of different types and lengths $(5 \mathrm{~m}, 9 \mathrm{~m}, 13 \mathrm{~m})$ of RVFS in reducing the suspended solids (SS) and nutrients from agricultural runoff. Three field experimental plots (T1-T2-T3) planted with weeds, sweet clover (Melilotus suaveolens L.) and sweet clover/Chinese wingnut (Pterocarya stenoptera C. DC.) were established adjacent to the agricultural edge from 2011 to 2018. The runoff volumes, SS, and nutrients concentrations were determined at each effective runoff event during the study periods. The results indicated that all RVFS (T1, T2, and T3) reduced the mass of the nutrients rather than the concentration in all runoff events. In the rainfall events, the pollutants were reduced significantly in the presence of RVFS. The removal efficiency of T2 and T3 amounted to $79 \%$ and $84 \%$ for SS within the first $5 \mathrm{~m}$, which was significantly higher than T1(61\%). The $9 \mathrm{~m}$-long T3 caused a significant reduction in the mean total phosphorus (TP) and dissolved phosphorus (DP) by $84 \%$ and $82 \%$, respectively. More than $70 \%$ of the pollutants from rainfall runoff could be controlled by a $13 \mathrm{~m}$ RVFS. The snow-melt events increased the risk of ANSP migrating to streams, especially for the DP. However, the Chinese wingnut strip increased the filtering capacity of the DP as compared
\end{abstract}

*e-mail: sunzx67@163.com

**e-mail: luoqingyt@126.com 
to the other two RVFS. Results from this study confirmed that the RVFS is a very effective mitigation system to reduce the sediment and nutrient loads in the agricultural runoff.

Keywords: riparian vegetated filter strips, nitrogen, phosphorus, suspended solids, rainfall, snowmelt

\section{Introduction}

Water pollution has become a major problem for both developed and developing countries in recent decades. Agricultural nonpoint source pollution caused water quality degradation in many countries [1-3]. Water quality in most Chinese rivers and groundwater sources is poor and declining because of the agricultural run-off of fertilizers, pesticides, and manure, causing widespread eutrophication that threatens human health [4]. The Yellow River, the Yangtze River, the Pearl River, and the more than 700 other rivers have issues of water eutrophication because of ANSP in China. Liao River is one of the most important rivers in Liaoning Province, northeastern China. Various unlawful agricultural activities lead to Liao River becoming severely polluted, in particular, the ammonia nitrogen content in some monitoring sections has exceeded the national standard value.

In recent years, an increasing number of studies have focused on the effectiveness of RVFS on reducing agricultural nonpoint source pollution [5-16]. RVFS can trap sediments, nutrients, and other contaminants to prevent their runoff before reaching adjacent water bodies [11]. Loads of nitrogen and phosphorus in shallow groundwater flowing through the riparian buffer zone that have been reported were reduced significantly [17-18]. Blanco-Canqui et al. [19] studied the effectiveness of grass barriers and RVFS in reducing ANSP. They found that $55 \%$ of organic $\mathrm{N}, 27 \%$ of $\mathrm{NO}_{3}^{-}$ $-\mathrm{N}, 19 \%$ of $\mathrm{NH}_{4}^{+}-\mathrm{N}, 36 \%$ of particulate, and $37 \%$ of $\mathrm{PO}_{4}^{3-}-\mathrm{P}$ were reduced in their experiment. Many factors affect the efficacy of RVFS in removing contaminants, including vegetation type, RVFS width, slope, soil, climate, topography, and hydrological processes, which influence their efficiency in trapping contaminants [20]. The 1-6 m wide riparian vegetated buffer strips could retain total nitrogen in the range of $19.4 \%-42.9 \%$ [21]. Alukwe and Dillaha [22] reported phosphorous trapping efficiency of $73 \%$ for a $4.6-\mathrm{m}$ width vegetated filter strips (VFS) with a slope of $11 \%$, whereas with a $16 \%$ slope, the trapping efficiency was $49 \%$ for the same width VFS. Lee et al. [5] found that the mixed switchgrass and wood buffer had a particularly higher capacity for removing the sediment, TN, and TP than the switchgrass buffer. Rahmana et al. [23] studied the effects of soil $\mathrm{pH}$ changes on the VFS performance and found that changing soil $\mathrm{pH}$ affected soluble nutrient transportation through VFS.

Together these studies have indicated that VFS reduced agricultural nonpoint source pollution significantly. However, information on cold climate plant filter strips is limited. Very few field studies have evaluated the effectiveness of RVFS in the Liao River, China. The objectives of this study were to (1) determine the effectiveness of sweet clover (Melilotus suaveolens L.) RVFS versus mixed sweet clover (Melilotus suaveolens L.)/Chinese wingnut (Pterocarya stenoptera C. DC.) RVFS in reducing runoff, nitrogen, and phosphorous under natural rainfall and snowmelt conditions, and (2) identify the effects of filter strips on ANSP.

\section{Materials and Methods}

\section{Study Location and Experiment Design}

The field experiment was conducted in the Liao River Basin at $42^{\circ} 19^{\prime} 763^{\prime \prime} \mathrm{N}, 123^{\circ} 50^{\prime} 410^{\prime \prime} \mathrm{E}$ in Tieling City, Liaoning Province, China. The average annual total precipitation, average daily minimum air temperature, and average daily maximum air temperature are $655 \mathrm{~mm},-13.7^{\circ} \mathrm{C}$, and $23.7^{\circ} \mathrm{C}$, respectively. Vegetative buffer treatments including weeds (T1), sweet clover (T2) and mixed sweet clover/ Chinese wingnut (T3) were established in 2011 (Figs 1, 2). The details and management of the establishment of the plots are given in Tang et al. [24]. In May 2015, the sweet clover was reseeded at the $15 \mathrm{~kg}$ $\mathrm{ha}^{-1}$ rates in each plot. The corn was planted annually during the study period and harvested in October.

\section{Sampling and Analysis}

The soil samples $(0-20 \mathrm{~cm}$ depth) were collected from farmland and RVFS in spring 2012 for soil characterization. The soil samples from different RVFS were collected in spring 2016 (Table 1). A single-ring infiltrometer was used to measure the infiltration date of RVFS during the summer 2013 and 2016 [25]. From June 2012 to September 2017, surface runoff samples

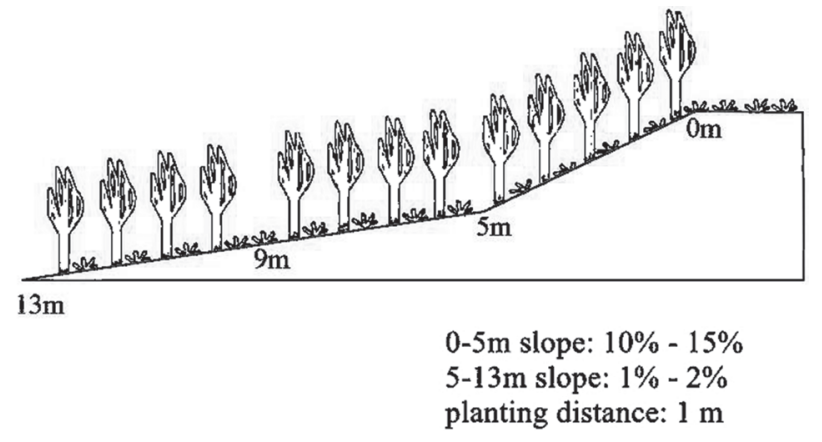

Fig. 1. Schematic depicting of RVFS plot arrangement. 


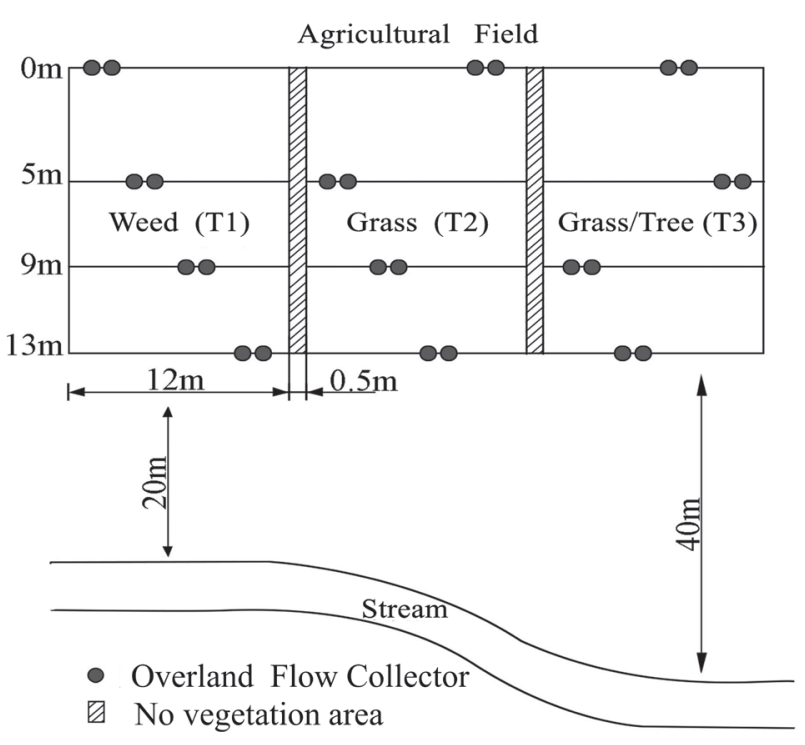

Fig. 2. Location of sampling sites.

of different widths RVFS were collected after each rainfall. The soil has high permeability and thus, not all rainfall can produce surface runoff. Therefore, a total of 45 surface runoff samples were collected. The runoff samples were not collected in 2014 and 2015 due to the repair and management of the riparian zone. Covered dustpan collectors designed by Daniels and Gilliam [26] were installed at $0 \mathrm{~m}$ (the cultivated land edge), 5, 9, and $13 \mathrm{~m}$ (horizontal distances) in random sites. The details of the sampling process were given in Tang et al. [24].

\section{Chemical and Statistical Analysis}

All the water samples were analyzed for total nitrogen (TN), total phosphorus (TP), nitrate $\left(\mathrm{NO}_{3}{ }^{-} \mathrm{N}\right)$, ammonium $\left(\mathrm{NH}_{4}^{+}-\mathrm{N}\right)$, and dissolved phosphorus (DP) using Continuous Flow Analysis (SKALAR SAN++). The water sample was fine-filtered through $0.45 \mu \mathrm{m}$ filters for the analysis of dissolved species, and TP and TN were determined from unfiltered samples. The physical and chemical properties of the soil were determined using conventional agricultural analysis methods. The precipitation data were collected from the hydrological station about $500 \mathrm{~m}$ away from the experimental site.

Non-parametric multiple comparisons with the Kruskal-Wallis test and Mann-Whitney-Wilcoxon U-test were used to assess the efficiency of different types of RVFS on runoff volumes and nutrient loads losses. A runoff and loss reduction factor were calculated as follows:

$$
\begin{aligned}
& R_{\text {runoff }}(\%)=\left(1-\frac{\mathrm{V}_{\mathrm{i}}}{\mathrm{V}_{0}}\right) \times 100 \\
& \operatorname{Rload}_{\text {lo }}(\%)=\left(1-\frac{C_{\mathrm{i}} V_{i}}{C_{0} V_{0}}\right) \times 100
\end{aligned}
$$

...where $\mathrm{R}$ is the removal rate of different distances RVFS in each treatment; $C_{0}$ and $C_{i}$ are the concentrations of nutrients in $\mathrm{mg} \mathrm{L}^{-1}$ from the field edge and after passing the 5, 9, and $13 \mathrm{~m}$ RVFS; and $V_{O}$ and $V i$ are the volumes of runoff from the cropland edge to different sampling sites. SPSS19.0 software was used for data analysis. The graphs were plotted using MS Excel 2007 and Origin 9.1.

\section{Results}

\section{Rainfall and Runoff}

A total of 45 rainfall events and 8 snowmelt events were analyzed during the study period. We recorded the rainfall and runoff volume that could generate overland flow in each study year. The rainfall situation in this area changed considerably during the study period. The rainfall and runoff amounts are shown

\begin{tabular}{|c|c|c|c|c|c|c|c|c|c|c|}
\hline Site & $\mathrm{pH}$ & $\begin{array}{c}\mathrm{OM} \\
\left(\mathrm{g} \cdot \mathrm{kg}^{-1}\right)\end{array}$ & $\begin{array}{l}\text { Sand } \\
(\%)\end{array}$ & $\begin{array}{l}\text { Clay } \\
(\%)\end{array}$ & Silt (\%) & $\begin{array}{l}\text { Total N } \\
\left(\mathrm{mg} \cdot \mathrm{kg}^{-1}\right)\end{array}$ & $\begin{array}{c}\text { Total } \\
\mathrm{P}\left(\mathrm{mg} \cdot \mathrm{kg}^{-1}\right)\end{array}$ & $\begin{array}{l}\text { Alkali-hy- } \\
\text { drolyzable N } \\
\left(\mathrm{mg} \cdot \mathrm{kg}^{-1}\right)\end{array}$ & $\begin{array}{c}\text { Available P } \\
\left(\mathrm{mg} \cdot \mathrm{kg}^{-1}\right)\end{array}$ & $\begin{array}{l}\text { Infiltration } \\
\text { rate } \\
\left(\mathrm{mm} \cdot \mathrm{h}^{-1}\right)\end{array}$ \\
\hline $\begin{array}{l}\text { Farm-Land } \\
\quad(2012)\end{array}$ & $\begin{array}{c}6.50 \pm \\
0.05\end{array}$ & $\begin{array}{c}2.01 \pm \\
0.02\end{array}$ & $\begin{array}{c}33.81 \pm \\
1.06\end{array}$ & $\begin{array}{c}9.21 \pm \\
0.32\end{array}$ & $\begin{array}{c}56.98 \pm \\
2.01\end{array}$ & $\begin{array}{l}1770 \pm \\
11.24\end{array}$ & $\begin{array}{c}577 \pm \\
11 . .06\end{array}$ & $\begin{array}{l}101 \pm \\
0.43\end{array}$ & $\begin{array}{l}30 \pm \\
0.52\end{array}$ & $\begin{array}{c}8.78 \pm \\
0.11\end{array}$ \\
\hline $\begin{array}{l}\text { Farm-Land } \\
\quad(2016)\end{array}$ & $\begin{array}{c}6.72 \pm \\
0.07\end{array}$ & $\begin{array}{c}1.77 \pm \\
0.06\end{array}$ & $\begin{array}{c}35.22 \pm \\
0.86\end{array}$ & $\begin{array}{c}10.23 \pm \\
0.42\end{array}$ & $\begin{array}{c}54.55 \pm \\
1.12\end{array}$ & $\begin{array}{l}1678 \pm \\
21.33\end{array}$ & $\begin{array}{c}560 \pm \\
7.36\end{array}$ & $\begin{array}{l}87 \pm \\
2.28\end{array}$ & $\begin{array}{l}24 \pm \\
1.17\end{array}$ & $\begin{array}{c}7.24 \pm \\
0.09\end{array}$ \\
\hline T1 (2012) & $\begin{array}{c}6.70 \pm \\
0.03\end{array}$ & $\begin{array}{c}2.47 \pm \\
0.04\end{array}$ & $\begin{array}{c}39.16 \pm \\
0.87\end{array}$ & $\begin{array}{c}8.32 \pm \\
0.37\end{array}$ & $\begin{array}{c}52.52 \pm \\
1.33\end{array}$ & $\begin{array}{l}1510 \pm \\
17.24\end{array}$ & $\begin{array}{l}416 \pm \\
12.21\end{array}$ & $\begin{array}{l}98 \pm \\
5.86\end{array}$ & $\begin{array}{l}32 \pm \\
0.73\end{array}$ & $\begin{array}{c}5.26 \pm \\
0.02\end{array}$ \\
\hline T1 (2016) & $\begin{array}{c}6.83 \pm \\
0.06\end{array}$ & $\begin{array}{c}3.56 \pm \\
0.05\end{array}$ & $\begin{array}{c}37.29 \pm \\
0.44\end{array}$ & $\begin{array}{c}9.22 \pm \\
0.11\end{array}$ & $\begin{array}{c}53.49 \pm \\
1.08\end{array}$ & $\begin{array}{c}1221 \pm \\
8.96\end{array}$ & $\begin{array}{c}368 \pm \\
4.63\end{array}$ & $\begin{array}{l}72 \pm \\
1.92\end{array}$ & $\begin{array}{l}19 \pm \\
0.77\end{array}$ & $\begin{array}{c}4.88 \pm \\
0.05\end{array}$ \\
\hline T2 (2016) & $\begin{array}{c}6.93 \pm \\
0.08\end{array}$ & $\begin{array}{c}5.22 \pm \\
0.09\end{array}$ & $\begin{array}{c}34.99 \pm \\
1.06\end{array}$ & $\begin{array}{c}10.23 \pm \\
0.53\end{array}$ & $\begin{array}{c}54.78 \pm \\
1.67\end{array}$ & $\begin{array}{l}1448 \pm \\
16.72\end{array}$ & $\begin{array}{c}409 \pm \\
6.06\end{array}$ & $\begin{array}{l}80 \pm \\
2.09\end{array}$ & $\begin{array}{l}15 \pm \\
0.32\end{array}$ & $\begin{array}{c}12.33 \pm \\
0.17\end{array}$ \\
\hline T3 (2016) & $\begin{array}{c}6.88 \pm \\
0.03\end{array}$ & $\begin{array}{c}4.26 \pm \\
0.08\end{array}$ & $\begin{array}{c}34.06 \pm \\
0.26\end{array}$ & $\begin{array}{c}10.18 \pm \\
0.05\end{array}$ & $\begin{array}{c}55.76 \pm \\
1.27\end{array}$ & $\begin{array}{c}1456 \pm \\
18.11\end{array}$ & $\begin{array}{l}417 \pm \\
9.16\end{array}$ & $\begin{array}{l}79 \pm \\
1.55\end{array}$ & $\begin{array}{l}20 \pm \\
0.71\end{array}$ & $\begin{array}{c}19.26 \pm \\
0.12\end{array}$ \\
\hline
\end{tabular}

Table 1. Soil characteristics of farmland and RVFS in different sampling periods. 


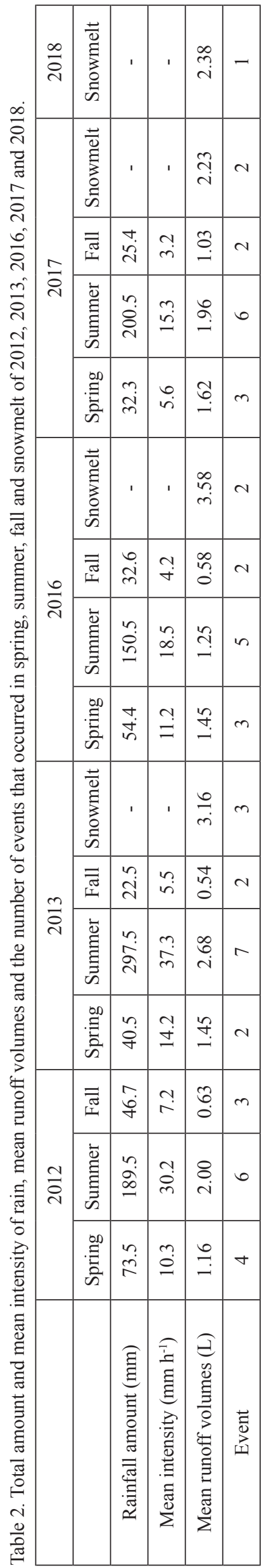

in Table 2. In terms of seasonal variation, the highest rainfall amount, intensity, and number of rainfall events were registered in summer, whereas the lowest values occurred in fall. The runoff volumes were correlated with the precipitation amounts. The highest rainfall intensity occurred in 2013, during which, two rainfall events exceeded $80 \mathrm{~mm}$. The mean runoff volumes from rainfall events were less due to the dry climate in 2016 and 2017. The snowmelt runoff was collected in the early spring of 2013, 2016-2018 for four years, the mean runoff volumes of snowmelt runoff were significantly greater than rainfall runoff.

\section{Mean Concentration of SS and Nutrients in RVFS}

As expected, T2 and T3 treatments significantly reduced SS in surface runoff samples as compared with $\mathrm{T} 1$ treatment in rainfall events. The concentration of SS decreased with the increase of RVFS width (Fig. 3a). The concentration of SS from snowmelt-induced runoff events was significantly higher than the concentration from rainfall events in all the RVFS. The average nutrient concentration of runoff from the $5 \mathrm{~m}$ or $9 \mathrm{~m}$ width RVFS was higher than the other widths for all the RVFS in the rainfall events (Fig. 3b-f). The slope of RVFS was $10 \%-15 \%$ in the first $5 \mathrm{~m}$, which resulted in increased concentrations of nutrients in the samples were collected in different sites. No differences were determined for the nutrient in the same width among $\mathrm{T} 1, \mathrm{~T} 2$, and $\mathrm{T} 3$.

The results obtained in different RVFS widths from the snowmelt events indicated that no significant differences $(\mathrm{P}>0.05)$ were observed for nitrogen and phosphorus. No significant differences $(\mathrm{P}>0.05)$ were also observed between the different RVFS regarding the same nutrient. The average DP concentration of snowmelt in the different sampling points was higher than rainfall, but the other parameters were the opposite, possibly because of the reduction of nutrients mass attributed to less fertilizer used.

\section{Mean Loads of Runoff, SS, and Nutrients} in Rainfall and Snowmelt Events within RVFS

The removal efficiency of the RVFS was calculated for ANSP based on the mean loads exported from $0 \mathrm{~m}$. The three RVFS could filter pollutants from farmland effectively (Fig. 4). Fig. 4 shows the distribution of the values of efficiency removal for pollutants grouped into vegetation types from a range of widths $(5,9$, and $13 \mathrm{~m})$ in rainfall and snowmelt events. For an RVFS of $5 \mathrm{~m}$, the T1, T2, and T3 caused a significant $(\mathrm{P}<0.05)$ reduction in the mean runoff volumes in the rainfall events by $57 \%, 62 \%$, and $71 \%$, respectively. The $\mathrm{T} 1, \mathrm{~T} 2$, and $\mathrm{T} 3$ in the rainfall events obtained $61 \%, 79 \%$, and $84 \%$ for the removal of SS; $38 \%, 55 \%$, and $56 \%$ for the removal of $\mathrm{NH}_{4}^{+}-\mathrm{N} ; 48 \%, 54 \%$, and $57 \%$ for the removal of $\mathrm{TN} ; 51 \%, 56 \%$, and $56 \%$ for the removal of $\mathrm{NO}_{3}^{-}-\mathrm{N}$; 

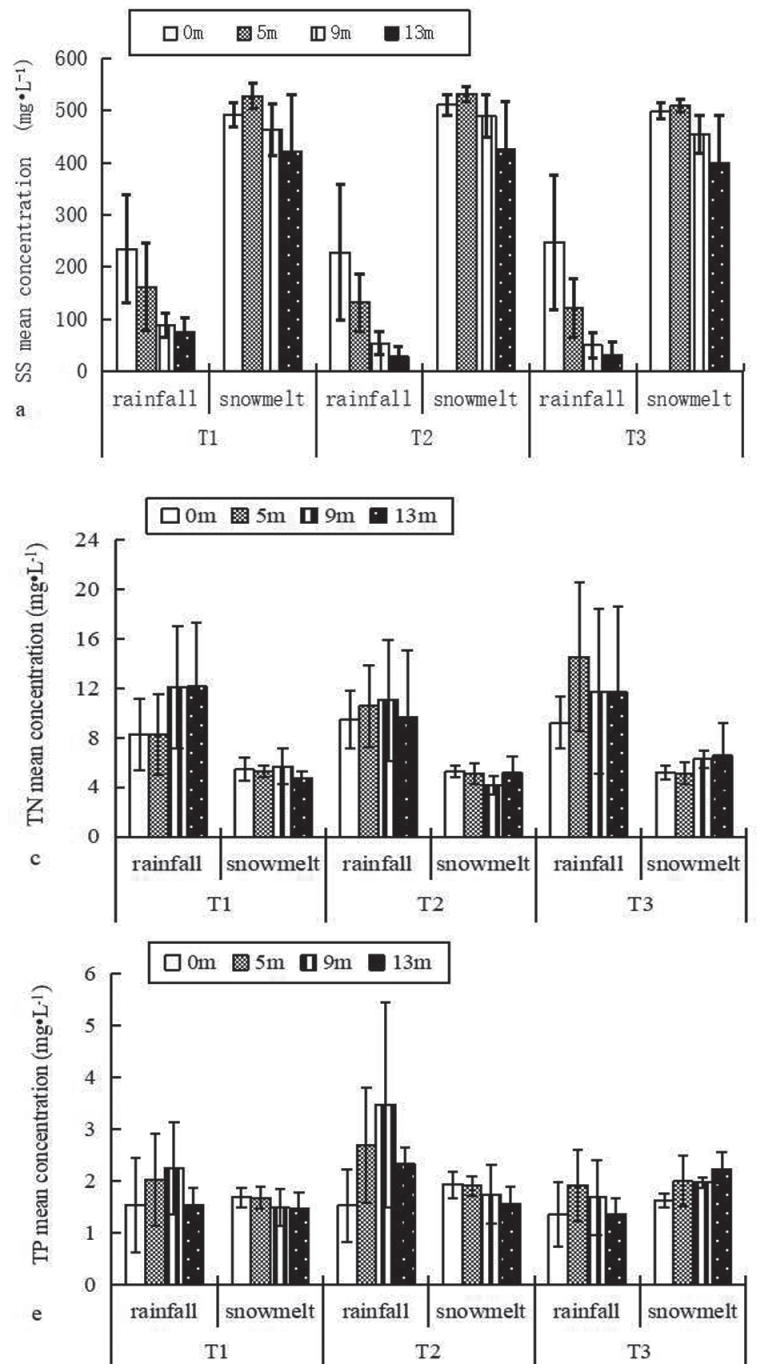
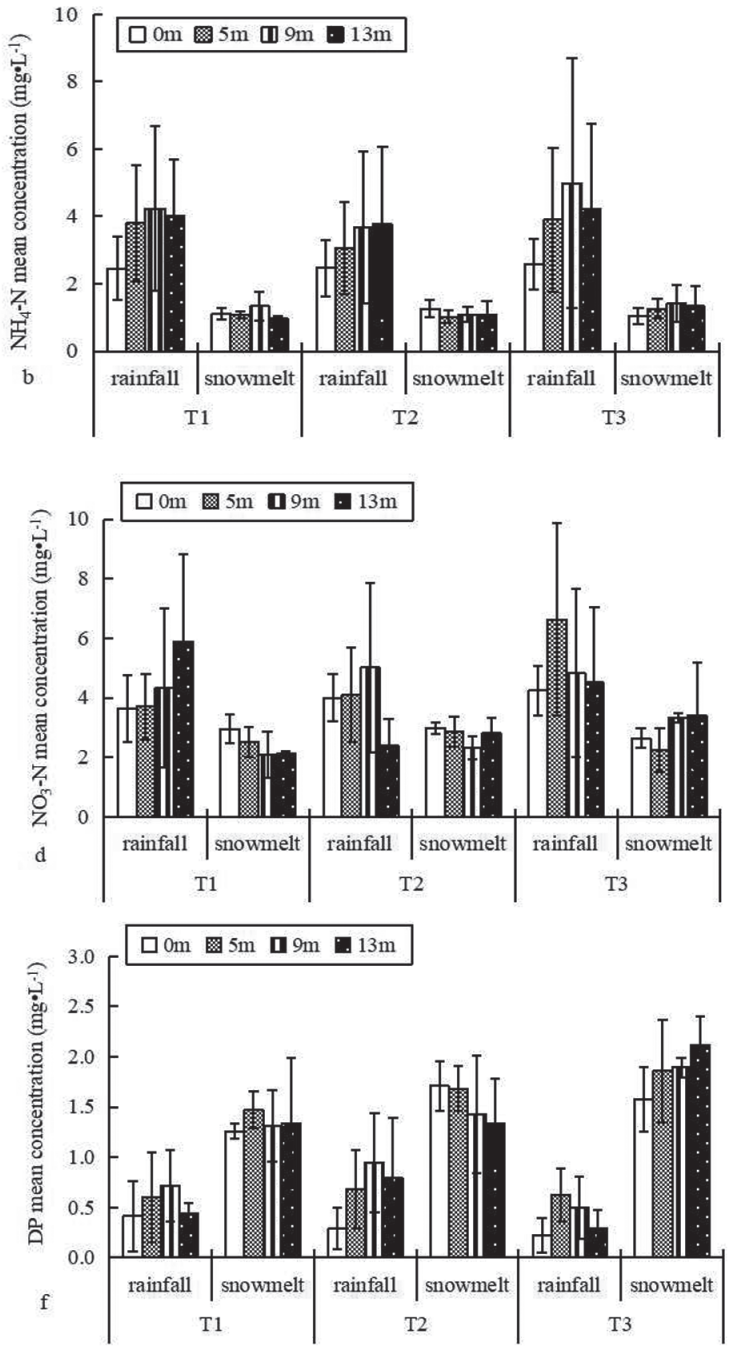

Fig. 3. Mean nutrient concentration at successive distances from the field edge in different RVFS during rainfall and snowmelt events.

$48 \%, 47 \%$, and $61 \%$ for removal of TP; and $43 \%, 47 \%$, and $53 \%$ for removal of DP. The removal efficiency of RVFS for the snowmelt runoff that occurred in the early spring was lower than that for rainfall runoff. The effectiveness of the $5 \mathrm{~m}$ RVFS appeared a negative value in some sampling periods. For the RVFS of $9 \mathrm{~m}$, in rainfall-induced surface runoff events, T1 was efficient in removing $78 \%$ runoff volumes, $90 \% \mathrm{SS}, 66 \%$ $\mathrm{NH}_{4}^{+}-\mathrm{N}, 73 \% \mathrm{TN}, 64 \% \mathrm{NO}_{3}^{-}-\mathrm{N}, 69 \% \mathrm{TP}$ and $59 \%$ of DP, and $\mathrm{T} 2$ was efficient in removing $80 \%$ runoff volumes, $95 \% \mathrm{SS}, 74 \% \mathrm{NH}_{4}^{+}-\mathrm{N}, 80 \% \mathrm{TN}, 73 \% \mathrm{NO}_{3}^{-}-\mathrm{N}, 68 \% \mathrm{TP}$, and $73 \%$ of DP. However, The attenuation efficiency when the Chinese wingnut was present in RVFS was $83 \%$ for runoff volumes, $96 \%$ for $\mathrm{SS}, 76 \%$ for $\mathrm{NH}_{4}^{+}-\mathrm{N}$, $82 \%$ for $\mathrm{TN}, 80 \%$ for $\mathrm{NO}_{3}^{-} \mathrm{N}, 85 \%$ for $\mathrm{TP}$, and $82 \%$ for DP. The removal efficiency of $\mathrm{T} 1$ for $\mathrm{NH}_{4}^{+}-\mathrm{N}(5 \%)$ and TN $(19 \%)$ were significantly $(\mathrm{P}>0.05)$ lower than T2 $\left(29 \%\right.$ for $\mathrm{NH}_{4}^{+}-\mathrm{N}, 39 \%$ for TN ) and T3 $(23 \%$ for $\mathrm{NH}_{4}^{+}-\mathrm{N}, 33 \%$ for $\mathrm{TN}$ ) from snowmelt events. No significant differences $(\mathrm{P}>0.05)$ were observed between the different RVFS regarding the removal efficiency of the other parameters. The removal efficiency increased from 9 to $13 \mathrm{~m}$ in each RVFS. The removal efficiency was more than $80 \%$ for RVFS of $13 \mathrm{~m}$ in rainfall events. In the range of $13 \mathrm{~m}$, the effective removal for $\mathrm{T} 1$ was calculated at $81 \%$ for runoff volumes, $94 \%$ for SS, $80 \%$ for $\mathrm{NH}_{4}^{+}-\mathrm{N}, 73 \%$ for $\mathrm{TN}, 75 \%$ for $\mathrm{NO}_{3}^{-}-\mathrm{N}, 82 \%$ for TP and $75 \%$ for DP. For the T2, the removal efficiency was $84 \%$ for runoff volumes, $96 \%$ for SS, $80 \%$ for $\mathrm{NH}_{4}^{+}-\mathrm{N}$, $80 \%$ for $\mathrm{TN}, 87 \%$ for $\mathrm{NO}_{3}^{-} \mathrm{N}, 85 \%$ for $\mathrm{TP}$ and $78 \%$ for DP. For the T3, the removal efficiency was $86 \%$ for runoff volumes, $97 \%$ for $\mathrm{SS}, 76 \%$ for $\mathrm{NH}_{4}^{+}-\mathrm{N}, 83 \%$ for TN, $88 \%$ for $\mathrm{NO}_{3}^{-}-\mathrm{N}, 92 \%$ for TP and $94 \%$ for DP. The removal efficiency of $\mathrm{T} 3$ for snowmelt runoff volumes and SS were significantly $(\mathrm{P}>0.05)$ higher than $\mathrm{T} 1$ and $\mathrm{T} 2$. The $13 \mathrm{~m} \mathrm{~T} 3$ strip obtained a retention capacity of $52 \%$ for snowmelt runoff volumes and $56 \%$ for SS.

\section{Accumulation of Nitrogen and Phosphorus in Different RVFS Plants}

Significant differences were observed between different RVFS as to the biomass of different vegetation types $(\mathrm{P}<0.05)$, and the biomass of the plants in each 

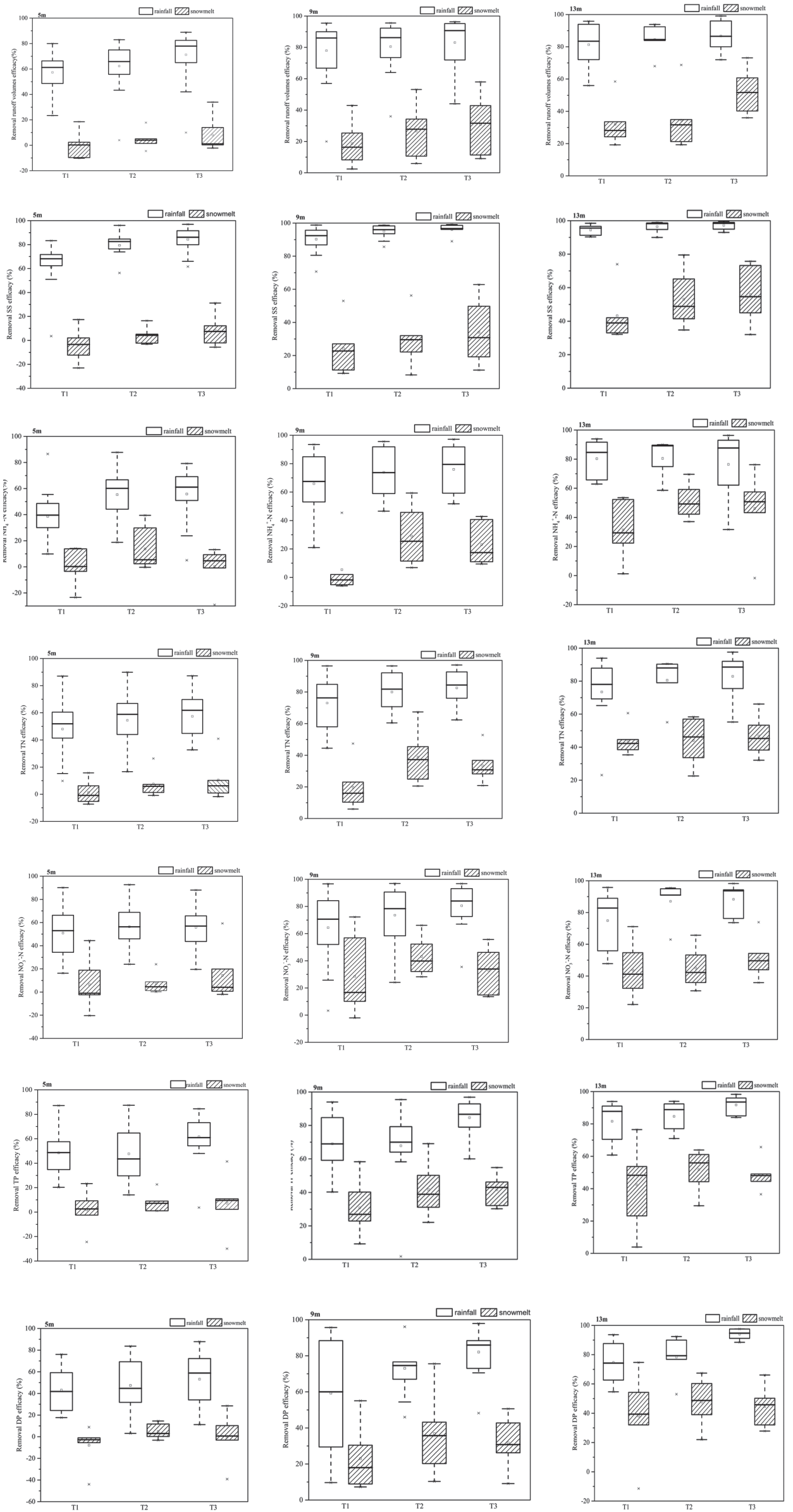

Fig. 4. Removal efficiency of runoff volumes, $\mathrm{SS}, \mathrm{NH}_{4}^{+}-\mathrm{N}, \mathrm{TN}, \mathrm{NO}_{3}^{-}-\mathrm{N}$, TP, and DP in different widths of each RVFS. 
Table 3. Biomass of aboveground and underground parts of different plants in RVFS.

\begin{tabular}{|c|c|c|c|c|}
\hline Vegetation types & Sample time & Aboveground & Underground & Total biomass \\
\hline \multirow{3}{*}{ T1 $^{\mathrm{a}}$} & 07.14 .2012 & $0.64 \pm 0.13 \mathrm{a}^{*}$ & $0.28 \pm 0.04 \mathrm{a}$ & $0.92 \pm \mathbf{0 . 0 7} \mathrm{a}$ \\
\cline { 2 - 5 } & 07.13 .2013 & $0.69 \pm 0.12 \mathrm{ab}$ & $0.27 \pm 0.06 \mathrm{a}$ & $0.96 \pm 0.14 \mathrm{a}$ \\
\cline { 2 - 5 } & 07.20 .2016 & $0.74 \pm 0.12 \mathrm{a}$ & $0.29 \pm 0.04 \mathrm{a}$ & $1.03 \pm 0.06 \mathrm{a}$ \\
\hline \multirow{3}{*}{ T2 $^{\mathrm{a}}$} & 07.14 .2012 & $0.71 \pm 0.09 \mathrm{~b}$ & $0.42 \pm 0.17 \mathrm{~b}$ & $1.13 \pm 0.21 \mathrm{~b}$ \\
\cline { 2 - 5 } & 07.13 .2013 & $0.84 \pm 0.13 \mathrm{c}$ & $0.49 \pm 0.11 \mathrm{~b}$ & $1.33 \pm 0.19 \mathrm{c}$ \\
\hline & 07.20 .2016 & $0.91 \pm 0.04 \mathrm{c}$ & $0.55 \pm 0.13 \mathrm{~b}$ & $1.46 \pm \mathbf{0 . 0 7 c}$ \\
\hline \multirow{3}{*}{$\mathrm{T}^{\mathrm{b}}$} & 07.14 .2012 & $6.59 \pm 1.34 \mathrm{~A}^{* *}$ & $2.14 \pm 0.99 \mathrm{~A}$ & $8.73 \pm 2.14 \mathrm{~A}$ \\
\hline & 07.13 .2013 & $9.97 \pm 1.78 \mathrm{~B}$ & $4.02 \pm 0.48 \mathrm{~B}$ & $13.99 \pm 2.08 \mathrm{~B}$ \\
\hline
\end{tabular}

a -Biomass: $\mathrm{kg} / \mathrm{m}^{2}$; b-Chinese Wingnut: $\mathrm{kg} /$ tree; ${ }^{*}$ Significant differences $(\mathrm{P}<0.05)$ are noted by different letters within a column;

**Significant differences $(\mathrm{P}<0.05)$ are noted by different letters within a column for Chinese Wingnut.

RVFS was also significantly different at different sampling times (Table 3). The aboveground biomass and underground biomass of weeds were 0.64-0.74 $\mathrm{kg} \cdot \mathrm{m}^{-2}$ and $0.27-0.29 \mathrm{~kg} \cdot \mathrm{m}^{-2}$, respectively. No significant difference was observed between the aboveground and underground biomass at different sampling times. The aboveground and underground biomass of sweet clover were $0.71-0.91 \mathrm{~kg} \cdot \mathrm{m}^{-2}$ and $0.42-0.55 \mathrm{~kg} \cdot \mathrm{m}^{-2}$, respectively. Significant differences were found between the aboveground biomass and other aboveground biomass in 2012, but the underground biomass was not significant. The aboveground and underground biomass of Chinese wingnut were $6.59-12.88 \mathrm{~kg} \cdot \mathrm{m}^{-2}$ and $2.14-7.21 \mathrm{~kg} \cdot \mathrm{m}^{-2}$, respectively. Among them, the biomass of Chinese wingnut changed the most, and the biomass increased with time, which reflected the strong growth ability of woody plants. The aboveground and underground biomass of sweet clover were larger than that of weeds. In general, the aboveground biomass of each plant was higher than the underground biomass.

The change range of TN and TP in the overground of weeds were 8.01-9.19 $\mathrm{g} \cdot \mathrm{m}^{-2}$ and $0.66-0.72 \mathrm{~g} \cdot \mathrm{m}^{-2}$, respectively, while that in the underground were $1.88-2.33 \mathrm{~g} \cdot \mathrm{m}^{-2}$ and $0.19-0.26 \mathrm{~g} \cdot \mathrm{m}^{-2}$, respectively (Table 4). The change range in the overground of sweet clover were $15.21-26.78 \mathrm{~g} \cdot \mathrm{m}^{-2}$ and $0.72-1.27 \mathrm{~g} \cdot \mathrm{m}^{-2}$, respectively, and that in the underground were $5.39-7.64 \mathrm{~g} \cdot \mathrm{m}^{-2}$ and $0.33-0.53 \mathrm{~g} \cdot \mathrm{m}^{-2}$. The accumulation of the aboveground was significantly higher than that of the underground. The data shows that the accumulation of TN and TP in the aboveground and underground parts of sweet clover were far greater than that of weeds. This observation is related to the fact that the biomass of sweet clover is larger than that of weeds. Among them, the accumulation of TN and TP in the aboveground and underground of Chinese wingnut were the largest, which was due mainly to the increase in the net biomass, which improved the accumulation capacity of $\mathrm{N}$ and $\mathrm{P}$.

\section{Discussion}

RVFS is a composite ecosystem of soil, plant, and microorganism. It has ecological effect according to the physical, chemical and biochemical reactions of the natural ecosystem. Through physical, chemical and biological functions, such as filtration, infiltration, absorption, retention, and sedimentation, it can reduce the degree of pollution entering the surface and groundwater [27-28]. In this study, what clearly emerged is the reduction of runoff volumes and SS in the presence of RVFS. Singh et al. [29] reported that RVFS significantly reduced the TSS and turbidity of runoff compared with corn and bare ground. Helmers et al. [12] showed that the trapping efficiency of sediment was $96 \%$ in their study period. The grass vegetation in RVFS has the effect of reducing flow velocities and total runoff volume from cropland [30-31]. Schoonover et al. [6] reported that a giant cane RVFS can reduce runoff by $100 \%$ because of the high infiltration rates of soils and reduced sediment loss by 94\% (3.3 m RVFS) compared with $86 \%$ (6.6 m RVFS). The infiltration rate measured during the study period follows the T3 $>$ T2 $>$ T1 $>$ farmland (Table 1).

Schoonover et al. [6] also reported similar values within the first $3.3 \mathrm{~m}$ or $6.6 \mathrm{~m}$ between the cane and forest buffer zone, in which the mean nutrient concentration increased then decreased with increasing filter width. Similar results were found in this study. In contrast, some prior studies have shown that the nutrient concentration was reduced significantly over wider distances in rainfall events [32-33]. Drayer et al. [34] reported that giant cane buffer reduced about 50\% concentration of $\mathrm{NO}_{3}^{-}-\mathrm{N}$ in stream water compared with the control. Alukwe and Dillaha [22] reported that RVFS could remove total N 54\% with $4.6 \mathrm{~m}$ width and by $73 \%$ with $9.1 \mathrm{~m}$ width, compared with bare ground. In this study, RVFS reduced loads of ANSP compared with the concentration, which was closely related to 
Table 4. Accumulation of nitrogen and phosphorus in the aboveground and underground parts of different plants in the different RVFS.

\begin{tabular}{|c|c|c|c|c|c|}
\hline \multirow{2}{*}{$\begin{array}{c}\text { Vegetation } \\
\text { types }\end{array}$} & Sample time & \multicolumn{2}{|c|}{$\mathrm{TN}$} & \multicolumn{2}{c|}{ TP } \\
\cline { 2 - 6 } & & Aboveground & Underground & Aboveground & Underground \\
\hline \multirow{3}{*}{ T1 $^{\mathrm{a}}$} & 07.14 .2012 & $9.19 \pm 1.12 \mathrm{a}^{*}$ & $2.33 \pm 0.19 \mathrm{a}$ & $0.72 \pm 0.09 \mathrm{a}$ & $0.26 \pm 0.04 \mathrm{a}$ \\
\cline { 2 - 6 } & 07.13 .2013 & $8.13 \pm \mathbf{1 . 0 3 \mathrm { a }}$ & $1.95 \pm 0.24 \mathrm{~b}$ & $0.68 \pm 0.21 \mathrm{a}$ & $0.19 \pm 0.08 \mathrm{~b}$ \\
\cline { 2 - 6 } & 07.20 .2016 & $8.01 \pm 1.11 \mathrm{a}$ & $1.88 \pm 0.21 \mathrm{~b}$ & $0.66 \pm 0.17 \mathrm{a}$ & $0.19 \pm 0.06 \mathrm{~b}$ \\
\hline \multirow{3}{*}{$2^{\mathrm{a}}$} & 07.14 .2012 & $15.21 \pm 2.13 \mathrm{~b}$ & $5.39 \pm 0.71 \mathrm{c}$ & $0.72 \pm 0.26 \mathrm{a}$ & $0.33 \pm 0.10 \mathrm{c}$ \\
\cline { 2 - 6 } & 07.13 .2013 & $23.66 \pm 3.01 \mathrm{c}$ & $6.98 \pm \mathbf{1 . 2 2} \mathrm{d}$ & $1.02 \pm 0.05 \mathrm{~b}$ & $0.42 \pm 0.14 \mathrm{~d}$ \\
\hline & 07.20 .2016 & $26.78 \pm 2.87 \mathrm{c}$ & $7.64 \pm 0.96 \mathrm{~d}$ & $1.27 \pm 0.10 \mathrm{c}$ & $0.53 \pm 0.33 \mathrm{~d}$ \\
\hline \multirow{3}{*}{$\mathrm{T}^{\mathrm{b}}$} & 07.14 .2012 & $77.89 \pm 5.76 \mathrm{~A}^{* *}$ & $18.38 \pm 3.16 \mathrm{~A}$ & $11.14 \pm \mathbf{1 . 2 1 \mathrm { A }}$ & $2.59 \pm 0.84 \mathrm{~A}$ \\
\cline { 2 - 6 } & 07.13 .2013 & $152.24 \pm 8.44 \mathrm{~B}$ & $44.98 \pm 2.37 \mathrm{~B}$ & $20.24 \pm 2.53 \mathrm{~B}$ & $6.07 \pm \mathbf{1 . 1 9} \mathrm{B}$ \\
\cline { 2 - 6 } & 07.20 .2016 & $178.59 \pm 5.22 \mathrm{C}$ & $60.87 \pm 3.23 \mathrm{C}$ & $26.89 \pm 3.47 \mathrm{C}$ & $9.33 \pm 0.55 \mathrm{C}$ \\
\hline
\end{tabular}

a-Biomass: $\mathrm{g} / \mathrm{m}^{2}$; b-Chinese Wingnut: $\mathrm{g} /$ tree; *Significant differences $(\mathrm{P}<0.05)$ are noted by different letters within a column;

$* *$ Significant differences $(\mathrm{P}<0.05)$ are noted by different letters within a column for Chinese Wingnut

the reduction of runoff volumes and SS. Pollutant retention increased significantly with sediment retention [35]. Vegetation increased the surface roughness of soil and the surface runoff velocity decreased significantly [13]. Some studies showed that TP retained by RVFS were mainly in the form of sedimentbound [36]. The plants also play an important role in intercepting agricultural non-point source pollutants. The interception efficiency of pollutants depends mainly on the vegetation type [37]. The reason why the sweet clover had high nitrogen retention efficiency was because it was a legume, which has good nitrogen fixation ability. In addition, the uptake nutrients capacity of woody plants might be higher than that of herbaceous plants [38].

The removal efficiency of RVFS for snowmelt runoff is low. The soil freezing reduced the storage capacity of the soil because of the melting and saturation of the snow on the surface of the soil. Vegetation is also rare, and the infiltration rate is limited during the snowmelt season [39], while the slightly steep slope in RVFS of $5 \mathrm{~m}$ might be a factor resulting from a decrease in retention efficiency. However, the concentration of DP was higher in snowmelt runoff than rainfall runoff. The DP was the majority of $\mathrm{P}$ in the snowmelt water [39]. Jamieson et al. [40] found that $99.8 \%$ of the surface runoff came from the snow melting events in Quebec, Canada, and TP and orthophosphate-P in snowmelt runoff accounted for $96.7 \%$ and $99.1 \%$ of total loads, respectively. The uptake of plants for nutrients was limited during winter, and thus, DP might be released from the senesced vegetation [41]. The release of nucleic acid and phospholipid might be an important mechanism because of the freezing action and the destruction of soil microbial cell membranes. In addition, fine root death might also cause an increase in the release of DP [42]. A close relationship was observed between the accumulation of nitrogen or phosphorus and the removal efficiency of RVFS for ANSP. In this study, the accumulation of $\mathrm{N}$ and $\mathrm{P}$ of sweet clover and Chinese wingnut were higher than weeds. Hence, harvesting of aboveground plants is an effective way to remove nitrogen and phosphorus from ANSP.

\section{Conclusions}

Sweet clover and Chinese wingnut were all effective RVFS species for reducing runoff volumes, sediment, and nutrients compared with the weeds. Our results showed that RVFS did not reduce the concentration of nutrients significantly, while loads of nutrients were reduced significantly by RVFS. RVFS width is an important factor in the removal of all nutrients. The widths of $5 \mathrm{~m}$ had great removal efficiency for loads of nutrients used in the study sites, especially for SS in rainfall events. The RVFS of 9-13 $\mathrm{m}$ has a higher efficiency for pollutants. The plants' uptake and soil permeability are also the main factors for the retention of RVFS. Harvesting of aboveground plants is an effective way to remove nitrogen and phosphorus from ANSP. RVFS exhibited limited retention effectiveness in snowmelt events. The freezing and thawing of RVFS resulted in an increase in DP from snowmelt runoff. However, although our research has proven the effectiveness of RVFS in the removal of ANSP, some problems remain. For example, we cannot quantify the contribution of plants, soils, and microorganisms to the reduction of ANSP. Better technologies and methods are required in carrying out relevant research in the future.

\section{Acknowledgments}

This work was funded by General Project for Scientific Research of Liaoning Provincial Education 
Department (LJ2019JL029), the National Natural Science Foundation of China (No. 41501548, 41807384), the China Postdoctoral Science Foundation (No. 2018M630304), and LiaoNing Revitalization Talents Program (XLYC1807056, XLYC1908013).

\section{Conflict of Interest}

The authors declare no competing interests.

\section{References}

1. LI Z., LI L., HUANG J.K. ScienceDirect The 'River Chief System and Agricultural Non-point Source Water Pollution Control in China [J]. Journal of Integrative Agriculture, 2-15, 2346, 2020.

2. CHEN W., YU S.A., HE X.Y. A comparative study on nitrogen and phosphorus concentration characteristics of twelve riparian zone species from upstream of hunhe river. Clean - Soil Air Water. 42 (4), 408, 2014.

3. CHA S.M., LEE S.W., CHO K.H., SUN H.L., KIM J.H. Determination of best management timing of nonpoint source pollutants using particle bins and dimensionless time in a single stormwater runoff event. Ecological Engineering. 90, 251, 2016.

4. LI D., JIANG X., WANG K., ZHENG B. The distribution of nitrogen speciation and sources of nitrate in the north of taihu lake. Environmental Earth Sciences, 75 (24), 1500, 2016.

5. LEE K.H., ISENHART T.M., SCHULTZ R.C., MICKELSON S.K. Multispecies riparian buffers trap sediment and nutrients during rainfall simulations. Journal of Environmental Quality. 29 (4), 1200, 2000.

6. SCHOONOVER J.E., CRIM J.F., WILLIARD K.W.J., GRONINGER J.W., ZACZEK J.J., PATTUMMA K. Nutrient sediment dynamics within buffer zone and sinkhole splay areas under extreme soil disturbance conditions. Environmental Management, 56, 618, 2015.

7. GERICKE A., NGUYEN H.H., FISCHER P., KAIL J., VENOHR M. Deriving a bayesian network to assess the retention efficacy of riparian buffer zones. Water, 12 (3), 617, 2020.

8. MANON J., JOHANNA F., BERND L. Effect of grass buffer strips on nitrate export from a tile-drained field site[J]. Agricultural Water Management, 208, 318, 2018.

9. DONG Y.F., XIONG D.H, SU Z.A., YANG D., ZHENG X.Y. Effects of vegetation buffer strips on concentrated flow hydraulics and gully bed erosion based on in situ scouring experiments. Land Degradation \& Development, 29 (6), 1, 2018.

10. KIETA K.A., OWENS P.N. Phosphorus release from shoots of Phleum pretense L. after repeated freeze-thaw cycles and harvests[J]. Ecological Engineering, 127, 204, 2019.

11. GENE S.M., HOEKSTRA P.F., HANNAM C., WHITE M., TRUMAN C., HANSON M.L. The role of vegetated buffers in agriculture and their regulation across canada and the united states. Journal of Environmental Management, 243 (1), 12, 2019.

12. HELMERS M.J., ZHOU X., ASBJORNSEN H., KOLKA R., TOMER M.D., CRUSE R.M. Sediment removal by prairie filter strips in row-cropped ephemeral watersheds. Journal of Environmental Quality, 41 (5), 1531, 2012.

13. AL-WADAEY A., WORTMANN C.S., FRANTI T.G., SHAPIRO C.A., EISENHAUER D.E. Effectiveness of grass filters in reducing phosphorus and sediment runoff. Water, Air, \& Soil Pollution. 223 (9), 5865, 2012.

14. YANG F.S., YANG Y.Q., LI H.E., CAO M.M Removal efficiencies of vegetation-specific filter strips on nonpoint source pollutants. Ecological Engineering, 82, 145, 2015.

15. PEAK S., GIL K. Correlation analysis of factors affecting removal efficiency in vegetative filter strips. Environmental Earth Sciences, 75 (1), 1, 2016.

16. CHEN H., GRIENEISEN M.L., ZHANG M. Predicting pesticide removal efficacy of vegetated filter strips, A metaregression analysis. Science of the Total Environment, 548-549, 122, 2016.

17. NOIJ I.G., HEINEN M., HEESMANS H.I., THISSEN J.T., GROENENDIJK P. Effectiveness of unfertilized buffer strips for reducing nitrogen loads from agricultural lowland to surface waters. Journal of Environmental Quality, 41 (2), 322, 2012.

18. NOIJ I.G.A.M., HEINEN M., HEESMANS H.I.M., THISSEN J.T.N.M., GROENENDIJK P. Effectiveness of buffer strips without added fertilizer to reduce phosphorus loads from flat fields to surface waters. Soil Use and Management, 29 (1), 162, 2013.

19. BLANCO-CANQUI H., GANTZER C.J., ANDERSON S.H., ALBERTS E.E., THOMPSON A.L. Grass barrier and vegetative filter strip effectiveness in reducing runoff, sediment, nitrogen, and phosphorus loss. Soil Science Society of America Journal, 68 (5), 1670, 2004.

20. ALLAIRE S.E., SYLVAIN C., LANGE S.F., THERIAULT G., LAFRANCE P. Potential efficiency of riparian vegetated buffer strips in intercepting soluble compounds in the presence of subsurface preferential flows. Plos One, 10 (7), 1, 2015.

21. LIN X.S., TANG J., LI Z.Y., LI H.Y. Finite element simulation of total nitrogen transport in riparian buffer in an agricultural watershed. Sustainability, 8 (3), 288, 2016.

22. ALUKWE I.A., DILLAHA T. Effects of Watershed Land Use Data on HSPF Water Quality in the Upper Opequon Watershed in northern Virginia, USA [J]. American Journal of Water Resources, 2 (3), 54, 2014.

23. RAHMANA A., RAHMANA S., CIHACEK L. Influence of soil $\mathrm{pH}$ in vegetative filter strips for reducing soluble nutrient transport. Environmental Technology, 35 (14), 1744, 2014.

24. TANG J., SUN L., SUN T., ZHANG H. Removal of agricultural non-point source pollutants by riparian vegetated filter strips from upstream of Liao River, China. Journal of Food, Agriculture and Environment, 11, 2152, 2013.

25. PIRASTRU M., CASTELLINI M., GIADROSSICH F., NIEDDA M. Comparing the hydraulic properties of forested and grassed soils on an experimental hillslope in a mediterranean environment. Procedia Environmental Sciences, 19, 341, 2013.

26. DANIELS R.B., GILLIAM J.W. Sediment and chemical load reduction by grass and riparian filters. Soil Science Society of America Journal, 60 (1), 246, 1996.

27. SHIN J., GIL K. Determination of removal efficiency using vegetative filter strips based on various efficiency evaluation methods. Environmental Earth Sciences, 73 (10), 6437, 2015.

28. ZAK D., KRONVANG B., CARSTENSEN M.V., HOFFMANN C.C., KJELDGAARD A., LARSEN 
S.E., AUDET J., EGEMOSE S., JORGENSEN C.A., FEUERBACH P., GERTZ F., JENSEN H. Nitrogen and phosphorus removal from agricultural runoff in integrated buffer zones. Environmental Science \& Technology, 52 (11), 6508, 2018.

29. SINGH G., SCHOONOVER J.E., WILLIARD K.W.J., SWEET A.L., STEWART J. Giant cane vegetative buffer for improving soil and surface water quality. Journal of Environmental Quality, 48 (2), 330, 2019.

30. ZHAO C.H., GAO J.E., HUANG Y.F., WANG G.Q., ZHANG M.J. Effects of Vegetation Stems on Hydraulics of Overland Flow Under Varying Water Discharges. Land Degradation \& Development, 27, 748, 2016.

31. ZHANG X., LI P., LI Z.B., YU G.Q., LI C. Effects of precipitation and different distributions of grass strips on runoff and sediment in the loess convex hillslope. Catena, 162, 130, 2018

32. AHMED I.U., SHOU W., GANG D.D. Nonpoint source pollution. Water Environment Research, 86 (10), 1875, 2014.

33. LIN Y.F., LIN C.Y., CHOU W.C., LIN W.T., WU C.F. Modeling of riparian vegetated buffer strip width and placement: a case study in shei pa national park, taiwan. Ecological Engineering, 23 (4-5), 327, 2014.

34. DRAYER A.N., SENA K.L., BARTON C.D., ANDREWS D.M. Long-term response of stream and riparian restoration at Wilson Creek, Kentucky USA. Ecological Research, 35, 246, 2017.

35. GIACCIO G.C.M., LATERRA P., APARICIO V.C., COSTA J.L. Glyphosate retention in grassland riparian areas is reduced by the invasion of exotic trees. PhytonInternational Journal Experimental Botany, 85, 108, 2016.
36. VANROBAEYS J.A., OWENS P.N., LOBB D.A., KIETA K.A., CAMPBELL J.M. Seasonal efficacy of vegetated filter strips for phosphorus reduction in surface runoff. Journal of Environmental Quality, 48 (4), 880, 2019.

37. REZA HABIBIANDEHKORDI., DAVID A.L., PHILIP N.F. Effectiveness of vegetated buffer strips in controlling legacy phosphorus exports from agricultural land. Journal of Environmental Quality, 48 (2), 314, 2019.

38. MOSET V., HILLE S., RUBK G.H., MLLER H.B., BAATTRUP-PEDERSEN A.. Indicators of biomass and methane yields in vegetated buffer strips. Journal of Cleaner Production, 210 (10), 337, 2018.

39. KIETA K.A., OWENS P.N., LOBB D.A., VANROBAEYS J.A., FLATEN D.N. Phosphorus dynamics in vegetated buffer strips in cold climates: a review. Environmental Reviews, 26, 255, 2018.

40. JAMIESON J.A., MADRAMOOTOO C.A., ENGRIGHT P. Phosphorus losses in surface and subsurface runoff from a snowmelt event on an agricultural field in Quebec. Canadian Biosystems Engineering, 45 (1), 8786, 2003.

41. HABIBIANDEHKORDI R., LOBB D.A., SHEPPARD S.C., FLATEN D.N., OWENS P.N. Uncertainties in vegetated buffer strip function in controlling phosphorus export from agricultural land in the canadian prairies. Environmental Science and Pollution Research, 24 (2), 1, 2020.

42. ROBERTS W.M., STUTTER M.I., HAYGARTH P.M. Phosphorus retention and remobilization in vegetated buffer strips: a review. [J]. Journal of Environmental Quality, 41 (2), 389, 2012. 